\title{
Entrepreneurial intentions: why people refuse entrepreneurship and how to improve entrepreneurship education
}

\author{
${ }^{1}$ Fernando C. Gaspar, ${ }^{2}$ Fernando M. Mota \\ ${ }^{1}$ I. Politécnico de Santarém, Portugal \\ ${ }^{2}$ Dynamic Network XXI, Portugal
}

\begin{abstract}
The purpose of this paper is to measure entrepreneurial intentions with a clear timeframe for the intended behavior, thus going beyond a measure of attitude. The main focus is on those who refuse the idea of becoming entrepreneurs, and to understand the reasons for this refusal, something literature has ignored so far.
\end{abstract}

Samples were collected in 2008 and2018allowing for a study on the progress and therefore revealing the results of the effort put in entrepreneurship education.

Our data shows that a) trusting one's own skills, b) valuing own job creation, c) valuing being one's own boss and d) valuing the independence associated with being an entrepreneur, all contribute to student's willingness to become entrepreneurs.

The results provide some important lessons for entrepreneurship education programs, because individuals who refuse:

- are less motivated to career factors and more worried about life quality aspects than would-be entrepreneurs.

- $\quad$ see more obstacles to creating startups than would-be entrepreneurs.

- $\quad$ trust less in their entrepreneurial skills than would-be entrepreneurs.

Implications for theory and practice are proposed, as these results can be used to improve entrepreneurship education. This new view on potential entrepreneurs' individual choices is presented as an advancement to the theory and to the present understanding of entrepreneurship.

Keywords: motivation, ability, obstacles, entrepreneurial intentions, non-entrepreneurs, entrepreneurship. 1 Introduction

In recent years entrepreneurship has become a key driver of employment and economic growth, making governments and educational institutions show an increasing interest in promoting entrepreneurship (Gieure, Benavides-Espinosa, \& Roig-Dobón, 2019; Shane, 2004; Shane \& Venkataraman, 2000).

For entrepreneurial activity, the increase of entrepreneurial intentions is key (Ajzen, 1991; Galanakis \& Giourka, 2017), even though not the only factor(Gubik \& Bartha, 2018). Studying what drives entrepreneurial intentions is therefore fundamental to develop entrepreneurship(Gaspar \& Pinho, 2007).

At the same time, university policies are progressively moving towards the design of academic entrepreneurship centers by encouraging their students, researchers and teachers to turn their findings into patents, spin-offs or technological and business licenses, thereby extending academic activities (Wood, 2009).

Some literature has concluded for the existence of a small but significant correlation between entrepreneurship education and entrepreneurial intentions, from a meta-analysis of 73 studies with a total sample size of 37,285 individuals (Bae, Qian, Miao, \& Fiet, 2014).

The purpose of this research is to study antecedents of entrepreneurial intentions among college students in Portugal and to analyze its evolution in the last decade. There is already a two decade history of teaching topics related to entrepreneurship in Portuguese polytechnic schools, so maybe it is time to see whether there is an evolution in students' entrepreneurial intentions. 
DOI: $\underline{10.51386 / 25815946 / \mathrm{ijsms}-\mathrm{v} 4 \mathrm{i} 4 \mathrm{p} 104}$

Volume: 4 Issue: 4

July to August 2021

https://www.ijsmsjournal.org

Entrepreneurship education at all levels of education is considered an important factor for the development of entrepreneurship, idea supported by a body of literature on entrepreneurial intentions mostly focused on higher education institutions and also at the high school level (Andreia, Maria José, \& Jorge, 2012; Aragon-Sanchez, Baixauli-Soler, \& Carrasco-Hernandez, 2017).Thus this study will for ways to improve entrepreneurship education. For that purpose, special attention will be given to those who do not declare an entrepreneurial intention. No judgment is passed on those who declare that they do not want to be entrepreneurs, which is an absolutely acceptable position, however, this work aims to help improve entrepreneurship education's capacity to convince people to join the entrepreneurial life.

First, special attention is dedicated to literature on entrepreneurial intentions, then methodology will be explained and in the next section the results will be analyzed. Finally, some conclusions will be put forward.

\section{Entrepreneurial Intentions in literature}

The literature on entrepreneurial intentions is vast and long, with some excellent reviews (Krueger, Reilly, \& Carsrud, 2000; Liñán \& Fayolle, 2015) that help the reader become aware of the state of the art.

Literature has shown that the inclusion of entrepreneurship courses in academic syllabuses contributes to increase students' intention to create their own businesses(Hsu, Shinnar, \& Powell, 2014; Israr \& Saleem, 2018; Shinnar, Pruett, \& Toney, 2009), as for students, the creation of new businesses also emerges as an alternative to face the difficulties of finding employment compatible with skills acquired at the university (Santarelli, Carree, \& Verheul, 2009).

Literature shows four main models that can be used to study entrepreneurial intentions: Shaper's model of the entrepreneurial event(Krueger et al., 2000), Ajzen's theory of planned behaviour (TPB)(Ajzen, 1991), Lüthje and Franke's psychological traits model (Franke \& Lüthje, 2004; Gieure et al., 2019) and the MOA (Motivation, Opportunity, Ability) model (Hui-Chen, Kuen-Hung, \& Chen-Yi, 2014).

This research will build upon MOA and TBP because of their widespread acceptance among academics and ability to predict human social behaviour.

Psychological traits and personality characteristics were left out of the scope of this study as some researchers using the Big Five model found them not to be determinant of entrepreneurial intentions (Cantner, Goethner, \& Silbereisen, 2017).

The TPB stipulates that intentions are predicted by a person's attitudes towards a behaviour(ATB), the perceived subjective norms, and the perceived behavioral control (PBC), which can be differentiated into internal and external control attitudes toward a behavior (ATB), the perceived subjective norms, and the perceived behavioral control (PBC), which can be differentiated into internal and external control (Ajzen, 2002a). The core assumption of TPB is that behavioral intentions are an additive function of three conceptually independent factors: attitude toward behaviour, subjective norms, and perceived behaviour control (Cantner et al., 2017).

The model we will use in this work assumes the existence of interaction between three explanatory elements (Doe, 2017; Hui-Chen et al., 2014; Krueger \& Brazeal, 1994) that make the MOA model but are actually very close to TPB: 1) motivation (defined as the degree to which the person feels an attraction to a particular behavior), which is very close to TPB's perception of desire,2) obstacles, or how the environment supports or poses difficulties to the behaviour, something very similar to TPB's subjective norms, 3)self-perceived capacity / perception of personal abilities (defined as the degree to which people consider themselves personally capable of performing this behaviour very close to TPB's perceived behavior control (Ang \& Hong, 2000; Entrialgo \& Iglesias, 2016; Serida Nishimura \& Morales Tristan, 2011; Sing \& De Noble, 2003).This model is also very close to Shaper's, where perceived desirability, perceived feasibility and propensity to act (Krueger et al., 2000) are replaced in this model by perception of desire (motivation), perception of viability (obstacles), and perception of skills.

Since some of the literature accounts for gender-related differences in entrepreneurial intentions (Branchet \& Kř́žková, 2015), social and demographic variables were also included in this research.

The model used in this research is presented in Figure 1. 


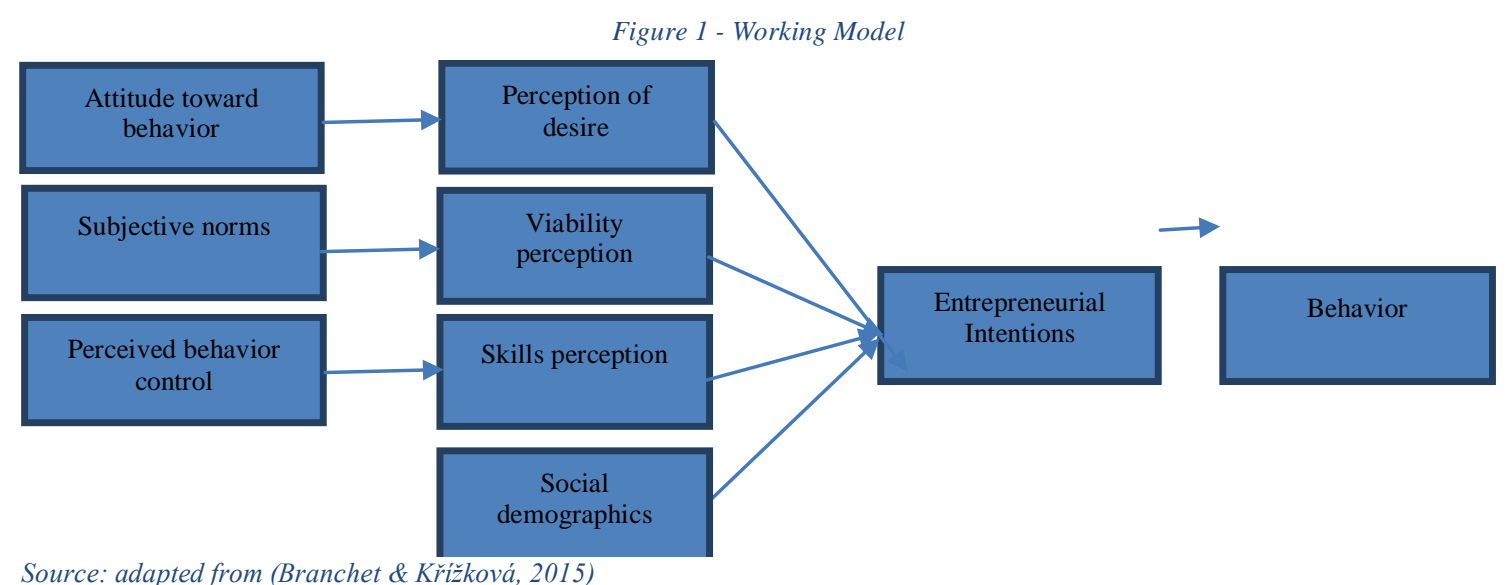

\section{Methods and data}

After studying the formation of entrepreneurial intentions and comparing the results of the data collected in 2008 and 2018, this research will then focus on the part of the samples where subjects declared no intention whatsoever of starting a company in the near or distant future.

Many studies have been published on entrepreneurship, with most of them studying successful entrepreneurs. Thus, most studies are focused on individuals who not only decided to create a startup but also succeeded at that activity.

Most studies don't consider people who created their startups and failed, and only very few consider those who decided not to become entrepreneurs.

So, this research looks at people who say flat out, at an early age (university final year students), they don't want to become entrepreneurs. They were asked whether they would like to a) start a company asap; b) start a company one day, later; c) never start a company. This study is focused on those who answered c).

A central question of this study is to identify what distinguishes these individuals from the those who want to be entrepreneurs and also why... Why don't they want to become entrepreneurs? Are they concerned they will not be successful? Do they believe they will not be able to assemble the necessary resources? Are they unable to identify entrepreneurial opportunities? Do they think society does not value entrepreneurs?

The answers to these questions will then be used to derive some proposals to upgrade entrepreneurship education.

Samples were collected in 2007/2008 and in 2017/2018, the first one with 264 students and the second with 354 students, all finalists from various polytechnic institutes in Portugal, with a larger share of students from the Polytechnic Institute of Santarem. The instrument used to collect this data was a questionnaire in Portuguese with Likert like 5-point scales, structured in 3 parts to evaluate: 1) motivation 2) perception of obstacles and 3) perception of their own ability to create a startup.

Finally, entrepreneurial intention was measured using a 3-point scale, grouping the samples in a) those who declare themselves willing to be an entrepreneur as soon as possible, b) those who declare they would like to become entrepreneurs later and c) those who declare they will never become an entrepreneur.

Data hinted a slight change in the gender composition of students during the decade, also showing a clear growth in entrepreneurial intentions (either immediate or later intents), with a sharp decrease in non-entrepreneurs (people who say they will never be entrepreneurs) from 62 to $11 \%$ (Figure 2). 
DOI: $\underline{10.51386 / 25815946 / i j s m s-v 4 i 4 p 104}$

Volume: 4 Issue: 4

July to August 2021

https://www.ijsmsjournal.org

Figure 2 - samples by gender and entrepreneurial intentions

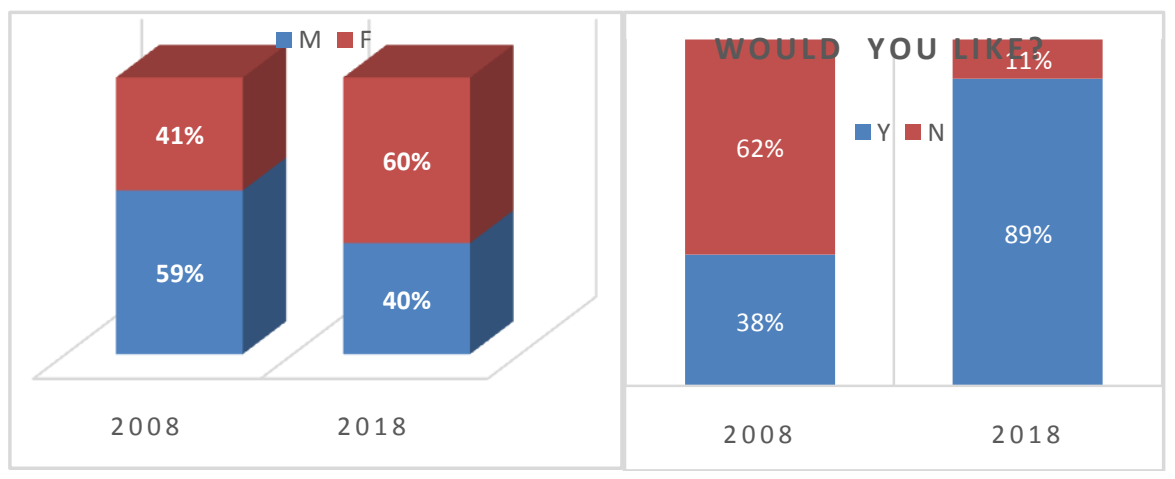

The model used in this research (Figure 1) is based on some assumptions that were tested as hypotheses.

Hypothesis 1 - motivations positively influence entrepreneurial intentions.

Hypothesis 2 - perceptions of obstacles negatively influence entrepreneurial intentions.

Hypothesis 3 - perception of own abilities negatively influences entrepreneurial intentions.

Hypothesis 4 - social demographic characteristics (gender, age, job status, international life experience, previous entrepreneurial experience and family entrepreneurial background) of students positively influence entrepreneurial intentions.

These hypotheses were tested using a regression analysis. Potential multi-collinearity problems were then examined by calculating the value inflation factors (VIF's). Moreover, the autocorrelation of residuals was tested (Durbin-Watson test). Finally, the plot of residuals versus predicted values was analysed to check the assumptions of homoscedasticity and linearity.

Attention was then turned to the non-entrepreneurs. Even though their numbers lowered considerably within a decade, they may nevertheless hold the secret to improve entrepreneurship education if we can answer the big question: why?

This was done by splitting the sample in two (entrepreneurs and non-entrepreneurs) and comparing them, looking for statistically significant differences, using Levine's F test.

Based on previous research (Pinho \& Gaspar, 2012) three additional hypothesis were added:

Hypothesis 5 - non-entrepreneurs value obstacles more ;

Hypothesis 6 - non-entrepreneurs have lower perception of their own skills.

Hypothesis 7 - non-entrepreneurs are less driven by professional and own job creation motivations.

\section{Results}

Cronbach's Alpha test was used to analyze the reliability of the constructs which was demonstrated to bequite acceptable (Table 1).

Table 1 - Cronbach's alpha test

\begin{tabular}{|c|c|c|}
\hline Cronbach's alpha results & 2008 & 2018 \\
\hline obstacles & .842 & .792 \\
\hline skill perceptions & .843 & .890 \\
\hline motivations & .775 & .739 \\
\hline
\end{tabular}

The validity of the scales was then checked, by analyzing content, convergent and discriminant validity.

Content validity was accepted since the scales had already been validated in a previously published work (Pinho \& Gaspar, 2012). 
DOI: $\underline{10.51386 / 25815946 / i j s m s-v 4 i 4 p 104}$

Volume: 4 Issue: 4

July to August 2021

https://www.ijsmsjournal.org

Principal component analysis was performed on the data to validate the scale. Principle Component Analysis requires that the probability associated with Bartlett's test of sphericity be less than the level of significance. The value of 0,000 confirmed the validity of the scale.

Comparison across the two samples revealed some correspondence between data on motivations, obstacles and skills from 2008 (Pinho \& Gaspar, 2012) and 2018 (Table 2).

Table 2 - motivations, obstacles and skills that stand out

\begin{tabular}{|l|l|l|}
\hline Top ranking & \multicolumn{1}{|c|}{2008} & \multicolumn{1}{|c|}{2018} \\
\hline Motivations & Professional development & \\
& Independence & $\begin{array}{l}\text { Independence } \\
\text { Fulfill dreams } \\
\text { Make money } \\
\text { Create } \\
\text { Job stability }\end{array}$ \\
\hline Obstacles & & $\begin{array}{l}\text { Lack of funding } \\
\text { Short personal financial resources } \\
\text { Financial risks }\end{array}$ \\
\hline Skills - I can... & $\begin{array}{l}\text { Lack of funding } \\
\text { Short personal financial resources }\end{array}$ & $\begin{array}{l}\text { Handle problems } \\
\text { Identify business opportunities } \\
\end{array}$ \\
& $\begin{array}{l}\text { Work in teams } \\
\text { Easily connect with people } \\
\text { Stand up for my ideas }\end{array}$ & \\
\hline
\end{tabular}

This analysis shows that motivations have clearly changed, with a growing emphasis on personal dreams. Perception of skills of the 2018 students apparently showed more confidence in their management skills, while the 2008 believed more in their social skills. Very curious to notice the top ranked obstacles did not change in a decade.

Regression analysis was then used to test the above listed hypotheses and determine what influences entrepreneurial intentions. The factors constructed for validity testing could have been used in the regression analysis, but they showed lower capacity to explain variance and were for that reason discarded. The summary of these regressions is shown in

Table 3.

Table 3 - regression analysis summary

\begin{tabular}{|c|c|c|c|c|c|}
\hline Sample & $\mathrm{R} 2$ & $\mathrm{~F}$ & $\begin{array}{l}\# \\
\text { relevantvariables }\end{array}$ & $\begin{array}{l}\text { Durbin- } \\
\text { Watson }\end{array}$ & $\begin{array}{ll}\text { Residuals } & \text { vs } \\
\text { predictions plot } & \\
\end{array}$ \\
\hline 2008 & ,566 & 11,553 & 4 & 1,633 & $\operatorname{good}^{1}$ \\
\hline 2018 &, 543 & 2,108 & 4 & 2,099 & good \\
\hline
\end{tabular}

Having no signs of homoscedasticity and since the model explained a fair amount of the variation, it was possible to realize that the number of relevant variables explaining this part of the variation in the dependent variable changed. In both 2008 and 2018samples,four variables contributed to student's choice of wanting to be entrepreneurs, though they were not the same, and the constant fell from one decade to the other (Table 4).

Table 4 - Coefficients

\begin{tabular}{|c|c|c|c|c|c|}
\hline & $\begin{array}{c}\text { Standard } \\
\text { Coefficien }\end{array}$ & & & \multicolumn{2}{|c|}{ CollinearityStatistics } \\
\hline 2008 & Beta & $\mathrm{t}$ & Sig. & Tolerance & VIF \\
\hline (Constant) & 2,033 & 9,485 &, 000 & & \\
\hline I know... developing new products and services &,- 497 & $-5,254$ &, 000 &, 971 & 1,030 \\
\hline Create one's own job &,- 444 & $-4,624$ & ,000 & ,943 & 1,060 \\
\hline I know... problem solving &,- 455 & $-4,707$ & ,000 & ,928 & 1,078 \\
\hline College transmits a positive idea about entrepreneurship & ,274 & 2,799 & 007 & ,908 & 1,102 \\
\hline 2018 & & & & & \\
\hline Be my own boss & $-0,194$ & $-2,610$ & 010 & 0,435 & 2,298 \\
\hline I know... Group work & $-0,130$ & $-2,173$ & 031 & 0,680 & 1,471 \\
\hline scientific area of degree & 0,138 & 2,171 &, 031 & 0,601 & 1,665 \\
\hline I know how... gather resources & $-0,127$ & $-2,125$ &, 034 & 0,679 & 1,473 \\
\hline
\end{tabular}

${ }^{1}$ Didn't show signs of homoscedasticity or normality assumptions violation 
DOI: $\underline{10.51386 / 25815946 / \mathrm{ijsms}-\mathrm{v} 4 \mathrm{i} 4 \mathrm{p} 104}$

Volume: 4 Issue: 4

July to August 2021

https://www.ijsmsjournal.org

\begin{tabular}{|l|r|r|r|r|r|}
\hline Have more free time & 0,149 & 2,034 &, 043 & 0,448 & 2,233 \\
\hline
\end{tabular}

This regression analysis further confirmed that trusting one's own skills contributes to individual's willingness to become entrepreneurs, thus partially confirming hyp. 3.

It also contributed to prove that people who value own job creation or being their own boss are more likely to be entrepreneurs, thus partially confirming hyp. 1.

The 2018 sample appears to value more the independence associated with being an entrepreneur (free time, be my own boss), also partially confirming hyp. 1.

In the final step of this research both 2008 and 2018 samples were divided between would-be entrepreneurs and non-entrepreneurs. Then comparisons were made for each year with a standard set of Levene's F test and student t-test (Table 5 and 6).

Table 5 - 2008's significantly different variables in NEs

\begin{tabular}{|c|c|c|c|c|c|c|c|c|}
\hline \multirow{2}{*}{2008} & \multirow[b]{2}{*}{ Var } & \multicolumn{3}{|c|}{$\begin{array}{c}\text { Levene's Test for Equality of } \\
\text { Variances }\end{array}$} & \multicolumn{4}{|c|}{ t-test for Equality of Means } \\
\hline & & $\mathrm{F}$ & Sig. & $\mathrm{t}$ & df & sig & MeanDifference & EqualVariances \\
\hline \multirow{2}{*}{ Motivations } & Createone'sown job & 0,428 & 0,514 & $-1,9594$ & 137,00 & 0,052 & $-0,979$ & Assumed \\
\hline & Professional development & 0,310 & 0,578 & $-2,8026$ & 139,00 & 0,006 & $-0,751$ & Assumed \\
\hline Obstacles & Assumingbigresponsabilities & 0,001 & 0,981 & 2,0227 & 137,00 & 0,045 & 0,515 & Assumed \\
\hline Skills & $\begin{array}{l}\text { Iniciative } \\
\text { Leadership and } \\
\text { Communicating }\end{array}$ & $\begin{array}{l}5,827 \\
0,347 \\
\end{array}$ & $\begin{array}{l}0,017 \\
0,557 \\
\end{array}$ & $\begin{array}{l}-2,1826 \\
-2,1875 \\
\end{array}$ & $\begin{array}{r}41,35 \\
138,00 \\
\end{array}$ & $\begin{array}{l}0,035 \\
0,030 \\
\end{array}$ & $\begin{array}{l}-0,376 \\
-0,384 \\
\end{array}$ & $\begin{array}{l}\text { Not assumed } \\
\text { Assumed } \\
\end{array}$ \\
\hline
\end{tabular}

NEs give less importance to the creation of their own job (0,979 less, in a 1 to 5 Likert scale, with $t=-1,959$, 137 degrees of freedom and $\mathrm{p}=0,052$ ) and don't value their professional development as much as would-be entrepreneurs do (0,751 less, $\mathrm{t}=2,8026,139 \mathrm{df}$ and $\mathrm{p}=0,006)$, thus confirming hyp. 7 .

On the other hand, NEs see the assumption of responsibilities that comes with the starting of a company as more of an obstacle to entrepreneurship than would-be entrepreneurs do $(0,515$ more, $t=2,0227,137 \mathrm{df}$ and $\mathrm{p}=0,045)$, thus confirming hyp. 5.

Finally, NEs are much less confident in their skills, particularly in initiative $(0,376$ less, $t=-2,1826,41 \mathrm{df}$ and $\mathrm{p}=0,035)$ and leadership and communicating $(0,384$ less, $\mathrm{t}=-2,1875,138$ df and $\mathrm{p}=0,03)$, thus partially confirming hyp. 6.

Table 6 - 2018's significantly different variables in NEs

\begin{tabular}{|c|c|c|c|c|c|c|c|c|}
\hline \multirow[t]{2}{*}{2018} & & \multicolumn{2}{|c|}{$\begin{array}{c}\text { Levene's Test } \\
\text { for Equality of } \\
\text { Variances }\end{array}$} & \multicolumn{4}{|c|}{ t-test for Equality of Means } & \multirow[b]{2}{*}{ EqualVariances } \\
\hline & & $\mathrm{F}$ & Sig. & $\mathrm{t}$ & df & sig & MeanDifference & \\
\hline \multirow{6}{*}{ Motivations } & Beherown boss & 1,54 & 0,215 & $-2,939$ & 349,00 & 0,00 & $-0,364$ & Assumed \\
\hline & Createone'sown job & 2,01 & 0,157 & $-3,793$ & 349,00 & 0,00 & $-0,459$ & Assumed \\
\hline & More free time & 6,62 & 0,010 & 2,266 & 53,60 & 0,03 & 0,271 & Not assumed \\
\hline & Having a fixedschedule & 13,72 & 0,000 & 2,803 & 55,67 & 0,01 & 0,337 & Not assumed \\
\hline & Facingchallenges & 8,33 & 0,004 & $-2,729$ & 49,79 & 0,01 & $-0,263$ & Not assumed \\
\hline & Creatingsomethingnew & 0,13 & 0,720 & $-2,899$ & 349,00 & 0,00 & $-0,312$ & Assumed \\
\hline \multirow{5}{*}{ Obstacles } & No business ideas & 0,01 & 0,910 & 3,167 & 349,00 & 0,00 & 0,430 & Assumed \\
\hline & Short business know-how & 0,13 & 0,721 & 2,023 & 349,00 & 0,04 & 0,275 & Assumed \\
\hline & No time & 0,57 & 0,452 & 3,363 & 349,00 & 0,00 & 0,488 & Assumed \\
\hline & Fear of failure & 0,79 & 0,375 & 2,242 & 349,00 & 0,03 & 0,341 & Assumed \\
\hline & Workinglonghours & 0,17 & 0,678 & 2,550 & 349,00 & 0,01 & 0,342 & Assumed \\
\hline Skills & I know... gatherresources & 17,35 & 0,000 & $-2,062$ & 45,64 & 0,04 & $-0,380$ & Not assumed \\
\hline
\end{tabular}


DOI: $\underline{10.51386 / 25815946 / i j s m s-v 4 i 4 p 104}$

Volume: 4 Issue: 4

July to August 2021

https://www.ijsmsjournal.org

\begin{tabular}{|r|r|r|r|r|r|r|r|r|r|}
\hline I know... develop new product ideas & 14,50 & 0,000 & $-2,307$ & 45,58 & 0,03 & $-0,382$ & Not assumed \\
\hline
\end{tabular}

In 2018 NEs still give less importance to the creation of their own job, but also give less importance than wouldbe entrepreneurs to being their own bosses, facing challenges or creating something new. On the contrary, they were more motivated to having more free time and having a fixed schedule.

NEs see higherobstacles than would-be entrepreneurs do and they did find more obstacles in 2018 than in 2008.

Finally, NEs trust less in their skills than would-be entrepreneurs do, with a difference: in 2008 they trusted less on their soft skills (initiative and leadership and communication) while in 2018 they mistrust specific entrepreneurial skills.

In short, NEs are less motivated to career factors and more worried about life quality factors than would-be entrepreneurs, they see more obstacles for creating startups than would-be entrepreneurs see and they trust less in their entrepreneurial skills than would-be entrepreneurs do.

\section{Conclusions}

The first note of conclusion as be the dramatic fall in the number of NE, students saying they would never (ever) be entrepreneurs. The dramatically high number of NEs revealed in 2008 came as a shock but after the Polytechnic schools spent ten years in improving entrepreneurship education(basically trying to make students see the creation of a startup more of a good thing, less of a big difficulty and more in range with their skills), students scored much higher entrepreneurial intentions.

Both samples showed that motivation and capabilities influenced entrepreneurial intentions (confirming the results of (Hien \& Cho, 2018)) as did the perceptions of own skills (confirming the results of (Hui-Chen et al., 2014)). This happened in both samples, even though the individual statistically significant items were not exactly the same, and thus hypotheses 1 and 3 were partially confirmed in both decades, while hypothesis 2 was not supported by the data.

NEs presented less trust in their own skills and saw higher obstacles to the start of a business. These are clear indications that entrepreneurship education needs improvement. Hypotheses 4, 5 and 6 were confirmed in both samples, thus providing guiding tools for practitioners (entrepreneurship education institutions) also opening new avenues for research on the reasons why some individuals exclude themselves from entrepreneurial life.

Further effort must be invested in the construction of entrepreneurship education to further increase entrepreneurial intentions, by decomplicating the perception students have about the obstacles to create a startup, by building up their trust in their own skills and by building a better image of the rewards provided by entrepreneurial careers.

Our conclusion is that studying the motivations and perceptions that lead individuals to choose to become or not to become entrepreneurs advances our understanding of entrepreneurship and should be included in future theory development.

The flagrant difference in motivations between the two samples should be interpreted in the context of cultural changes amongst youths, something that can be better understood in a more interdisciplinary study.

This shows some of the limitations in this research, to which one should add the geographical limitation of the samples, as well as the exclusion of some areas of undergraduate studies that are not present in polytechnic schools such as medicine, law and some others.

\section{Bibliography}

[1] Ajzen, I. (1991). The Theory of Planned Behavior. ORGANIZATIONAL BEHAVIOR AND HUMAN DECISION PROCESSES, 50, 179-211. https://doi.org/10.1922/CDH_2120VandenBroucke08

[2] Andreia, R., Maria José, S., \& Jorge, S. (2012). Intenções empreendedoras dos estudantes do ensino secundário: o caso do prog rama de empreendedorismo na escola. Economia Global e Gestão, 77-97. Retrieved from http://www.scielo.mec.pt/scielo.php?pid=S087374442012000400005\&script=sci_arttext\&tlng=es\%5Cnhttp://www.scielo.gpeari.mctes.pt/scielo.php?script=sci_arttext\&pid=S0873$74442012000400005 \&$ lang $=$ pt

[3] Ang, S. H., \& Hong, D. G. P. (2000). Entrepreneurial spirit among East Asian Chinese. Thunderbird International Business Review, 42(3), 285-309. https://doi.org/10.1002/1520-6874(200005/06)42:3<285::aid-tie2>3.0.co;2-5 


\section{DOI: $10.51386 / 25815946 / \mathrm{ijsms}-\mathrm{v} 4 \mathrm{i} 4 \mathrm{p} 104$}

Volume: 4 Issue: 4

July to August 2021

https://www.ijsmsjournal.org

[4] Aragon-Sanchez, A., Baixauli-Soler, S., \& Carrasco-Hernandez, A. J. (2017). A missing link: the behavioral mediators between resources and entrepreneurial intentions. International Journal of Entrepreneurial Behaviour and Research, 23(5), 752-768. https://doi.org/10.1108/IJEBR-06-2016-0172

[5] Bae, T. J., Qian, S., Miao, C., \& Fiet, J. O. (2014). The Relationship Between Entrepreneurship Education and Entrepreneurial Intentions: A Meta-Analytic Review. Entrepreneurship: Theory and Practice, 38(2), 217-254. https://doi.org/10.1111/etap.12095

[6] Branchet, B., \& Kř́žková, A. (2015). Gender and entrepreneurial intentions in a transition economy context: case of the Czech Republic. Int. J. Entrepreneurship and Small Business, 25(3), 260-281.

[7] Cantner, U., Goethner, M., \& Silbereisen, R. K. (2017). Schumpeter's entrepreneur - A rare case. Journal of Evolutionary Economics, 27(1), 187-214. https://doi.org/10.1007/s00191-016-0467-3

[8] Crant, M. J. (1996). Title: The proactive personality scale as a predictor of entrepreneurial intentions. charts THE PROACTIVE PERSONALITY SCALE AS A PREDICTOR OF ENTREPRENEURIAL INTENTIONS. Journal of Small Business Management, 34(3), 42-49. Retrieved from https://pdfs.semanticscholar.org/08b1/e75c304add9ab462e40825496b7c87848537.pdf

[9] Doe, R. (2017). Entrepreneurship among Non-Business Students: Implications for Entrepreneurship Education. American Journal of Management, 17(7), 24-32.

[10] Entrialgo, M., \& Iglesias, V. (2016). The moderating role of entrepreneurship education on the antecedents of entrepreneurial intention. International Entrepreneurship and Management Journal, 12(4), 1209-1232. https://doi.org/10.1007/s11365-016-0389-4

[11] Franke, N., \& Lüthje, C. (2004). Entrepreneurial intentions of business students - A benchmarking study. International Journal of Innovation and Technology Management, 1(3), 269-288. https://doi.org/10.1142/S0219877004000209

[12] Galanakis, K., \& Giourka, P. (2017). Entrepreneurial path: decoupling the complexity of entrepreneurial process. International Journal of Entrepreneurial Behaviour and Research, 23(2), 317-335. https://doi.org/10.1108/IJEBR-03-2016-0079

[13] Gaspar, F. C., \& Pinho, L. F. (2007). Environmental determinants of firm creation across Portuguese regions. ISBE 2007 - Institute for Small Business \& Entrepreneurship 30th Edition.

[14] Gieure, C., Benavides-Espinosa, M. del M., \& Roig-Dobón, S. (2019). Entrepreneurial intentions in an international university environment. International Journal of Entrepreneurial Behavior \& Research, IJEBR-12-2018-0810. https://doi.org/10.1108/IJEBR-122018-0810

[15] Gubik, A. S., \& Bartha, Z. (2018). Cultural Characteristics and the Entrepreneurial Intentions of University Students. Journal of Economic Literature, 13(2), 3-12. https://doi.org/10.18096/tmp.2017.02.01

[16] Hien, D. T. T., \& Cho, S. E. (2018). The effect of software developers' capabilities on entrepreneurial intention in ICT industries. International Journal of Entrepreneurship, 22(3), 1-18.

[17] Hsu, D. K., Shinnar, R. S., \& Powell, B. C. (2014). EXPECTANCY THEORY AND ENTREPRENEURIAL MOTIVATION: A LONGITUDINAL EXAMINATION OF THE ROLE OF ENTREPRENEURSHIP EDUCATION. Journal of Business \& Entrepreneurship, 26(1), 121-140.

[18] Hui-Chen, C., Kuen-Hung, T., \& Chen-Yi, P. (2014). The entrepreneurial process: an integrated model. International Entrepreneurship and Management Journal, 10(4), 727-745. https://doi.org/10.1007/s11365-014-0305-8

[19] Israr, M., \& Saleem, M. (2018). Entrepreneurial intentions among university students in Italy. Journal of Global Entrepreneurship Research, 8(1). https://doi.org/10.1186/s40497-018-0107-5

[20] Krueger, N. F., \& Brazeal, D. V. (1994). Entrepreneurial Potential \& Potential Entrepreneurs. Entrepreneurship Theory and Practice, $18(3), 91-104$

[21] Krueger, N. F., Reilly, M. D., \& Carsrud, A. L. (2000). Competing models of entrepreneurial intentions. Journal of Business Venturing, 15(5), 411-432. https://doi.org/10.1016/S0883-9026(98)00033-0

[22] Liñán, F., \& Fayolle, A. (2015). A systematic literature review on entrepreneurial intentions: citation, thematic analyses, and research agenda. International Entrepreneurship and Management Journal, 11(4), 907-933. https://doi.org/10.1007/s11365-015-0356-5

[23] Pinho, L. M., \& Gaspar, F. A. (2012). Intenção Empreendedora dos Estudantes no Ensino Superior Politécnico em Portugal. Jornadas Luso-Espanholas de Gestão Científica.

[24] Santarelli, E., Carree, M., \& Verheul, I. (2009). Unemployment and firm entry and exit: An update on a controversial relationship. Regional Studies, 43(8), 1061-1073. https://doi.org/10.1080/00343400801968361

[25] Serida Nishimura, J., \& Morales Tristan, O. (2011). Using the theory of planned behavior to predict nascent entrepreneUrship. Academia, Revista Latinoamericana de Administración, 46, 55-71. 
DOI: $10.51386 / 25815946 / \mathrm{ijsms}-\mathrm{v} 4 \mathrm{i} 4 \mathrm{p} 104$

Volume: 4 Issue: 4

July to August 2021

https://www.ijsmsjournal.org

[26] Shane, S. (2004). Academic Entrepreneurship: University Spinoffs and Wealth Creation. Cheltenham: Edward Elgar.

[27] Shane, S., \& Venkataraman, S. (2000). The Promise of Entrepreneurship as a Field of Research. Academy of Management Review, 25(1), 217-226. https://doi.org/10.2307/259271

[28] Shinnar, R. S., Pruett, M., \& Toney, B. (2009). Entrepreneurship Education : Attitudes Across Campus. The Journal of Education for Business, 84(3), 151-159. https://doi.org/10.3200/JOEB.84.3.151-159

[29] Sing, G., \& De Noble, A. (2003). Views on self-employment and personality: an exploratory study. Journal of Developmental Entrepreneurship, 8(3), 265-281.

[30] Wood, M. S. (2009). Does one size fit all? The multiple organizational forms leading to successful academic entrepreneurship. Entrepreneurship: Theory and Practice, 33(4), 929-947. 